Dostępne online www.journals.wco.pl/los

Zeszyty Naukowe WCO, Letters in Oncology Science 2018;15(1):6-10

CrossMark
Praca poglądowa/Review paper
Letters in Dncology Science

ISSN 2543-6724

ZESZYTY NAUKOWE WIELKOPOLSKIEGO CENTRUM ONKOLOGII

\title{
Optymalizacja czasu pracy i zarządzanie w zakładzie radioterapii
} w świetle doniesień zaprezentowanych podczas konferencji ESTRO 35 w Turynie

\section{Optimization of work time and management in a radiotherapy department in the light of reports presented at the ESTRO 35 conference in Turin}

\section{Artur Machtyl ${ }^{1}$}

${ }^{1}$ Zakład Radioterapii I, Wielkopolskie Centrum Onkologii, Poznań, Polska

\section{Streszczenie}

Celem pracy jest zwrócenie uwagi na najnowsze trendy i rozwiązania podnoszące efektywność i bezpieczeństwo pracy w Zakładach Radioterapii. Analizę oparto o wybrane raporty oraz problemy badawcze zaprezentowane podczas konferencji ESTRO 35 w Turynie.

\begin{abstract}
The aim of this paper is to identify the latest trends and solutions raising the efficacy and safety at radiotherapy departments. The analysis is based $\mathrm{n}$ selected reports and research problems as presented at the ESTRO 35 conference in Turin.
\end{abstract}

Stowa kluczowe: bezpieczeństwo, zarządzanie, radioterapia

Keywords: safety, management, radiotherapy

Adres do korespondencji

Artur Machtyl

Zakład Radioterapii I

Wielkopolskie Centrum Onkologii, ul. Garbary 15, 61-866 Poznań, Polska

Telefon. +48 618850731; Fax.++48 618850935

e-mail: artur.machtyl@wco.pl 


\section{Wstęp}

„Optymalizacja pracy w zakładzie radioterapii - wprowadzenie do myślenia szczupłego” (ang. lean thinking) to temat przewodni jednego z sympozjów odbywającego się podczas konferencji ESTRO 35 w dniach 29.04 - 03.05.2016 r. w Turynie.

Obok rozwoju nowoczesnych technologii i metod w radioterapii poszukiwane są rozwiązania pozwalające na podnoszenie efektywności pracy personelu oraz poprawę bezpieczeństwa leczenia pacjentów. Na sesji ESTRO 35 poświęconej zarządzaniu w służbie zdrowia przedstawiono szeroką gamą rozwiązań oraz kompleksowych systemów zarządzania, pomagających wykorzystywać efektywniej pracę całego personelu zakładów radioterapii. Omawiano także proces podnoszenia kultury pracy w radioterapii i związanej z nim maksymalizacji bezpiecznego leczenia pacjentów. Zagadnienia te zobrazowano przykładem działalności Kliniki MAASTRO (Maastricht Radiation Oncology, Holandia) oraz kompleksową analizą zachorowalności na nowotwory w Austrii, ze szczególnym uwzględnieniem wpływu zmian demograficznych na plany rozbudowy nowych ośrodków radioterapii.

\section{Najistotniejsze wnioski}

Sympozjum: Zarządzanie i optymalizacja pracy w oparciu o filozofię ,,Szczupłego myślenia”.

Szczupłe myślenie to koncepcja optymalizacji zarządzania przedsiębiorstwem, rozwinięta w oparciu o zasady i narzędzia systemu produkcyjnego Toyoty w latach 1948-1975 a od lat 90 wdrażana również poza przemysłem, między innymi w służbie zdrowia (lean healthcare). Najważniejszą zasadą szczupłego zarządzania jest określenie celu w postaci wartości dla klienta, czy to w postaci produktu czy usługi, ponieważ tylko zdefiniowanie celu pozwala na eliminację czynności, które wartości nie dodają. Czynności marnotrawne, czyli te, które wartości nie dodają muszą zostać wyeliminowane. Wyodrębniono cztery komponenty szczupłego zarzadzania konieczne do osiągnięcia celu: poprawa wykrywania błędów, zrozumienie procesu, zorganizowanie i właściwe zaprojektowanie procesu oraz usprawnienie współpracy. W medycynie myślenie szczupłe nakierowane jest na wydajność procedur medycznych maksymalizujących dobrostan pacjentów (wartość dodana). Pracownicy ochrony zdrowia powinni zatem szukać sposobów rozwiązywania problemów oraz ograniczania marnowania zasobów tak by leczyć lepiej i szybciej. Przykłady zastosowania szczupłego zarządzania w służbie zdrowia wskazują, że może to być podejście skuteczne [1].

Systemy zarządzania, w których zastosowano metody 'szczupłego myślenia’ opisywano w odniesieniu do różnych specjalności klinicznych. W zestawieniu literatury, radioterapia, z wynikiem jednej opublikowanej pracy, wypada bardzo słabo. Trudno ocenić na ile jest to wynik niestosowania konkretnych metod a na ile brak ich opisu. W wielu przypadkach opisywane procedury dotyczą jednak całych szpitali a nie konkretnych specjalności. W Virginia Mason Medical Center wprowadzono na przykład aż 175 usprawnień, których efektywność mierzono na przestrzeni dwóch lat (2002-4). Wyniki są znaczące: 65\% spadek czasu wdrażana procedur, 53\% spadek ilości zapasów, 36\% wzrost wydajności pracy, czy $41 \%$ zmniejszenie wynajmowanej powierzchni.

Eliminacja marnotrawstwa to kluczowy element szczupłego zarządzania. Do najpowszechniejszych przykładów marnotrawstwa czasu i środków w szpitalach zalicza się: nadprodukcję niepotrzebnych procedur diagnostycznych, nieuzasadniony ruch pracowników między stanowiskami, koszty transportu (np. transport próbek krwi), nadmierne przetwarzanie (np. przesadnie rozbudowane formularze) oraz niewykorzystany potencjał ludzki. Gdy zbadano rozkład czasu pracy pielęgniarek na oddziałach chirurgicznych , okazało się, że jedynie $77,7 \%$ czasu jest przeznaczone na pracę kliniczną, około $13 \%$ czasu na prace inne a blisko $7 \%$ jest marnowane [2].

Opieka nad pacjentami z przerzutami do kości i mózgu, poddanymi leczeniu za pomocą radioterapii, stanowi przykład zastosowania ‘szczupłego myślenia' [3]. Pacjenci z przerzutami do mózgu i kości powinni być poddani leczeniu natychmiast po zdiagnozowaniu. Okoliczności te sprzyjają testowaniu różnorakich strategii, w tym opierających się o filozofię szczupłego myślenia. Tego typu implementację i analizę przeprowadzono w odniesieniu do systemu zdrowia na Uniwersytecie Michigan. Jakkolwiek analiza efektów nie poddaje się rygorom projektu badawczego; nie testowano wpływu zastosowanych reguł na satysfakcję pacjentów, co jest zasadniczą miarą wartości dodanej i istotą filozofii szczupłego myślenia; wnioski skłaniają 
do refleksji. Już sam fakt znacznego przyspieszenia procedur sugeruje, że efekt musiał być satysfakcjonujący dla pacjentów. Na szczególną uwagę zasługuje jednak zastosowanie tzw. procesu mapowania przepływu wartości. Proces ten polega na stworzeniu diagramu opisującego szczegółowo kolejne działania i procesy niezbędne do wykonania pacjentowi konkretnego zabiegu czy też dostarczenia usługi. Idea wprowadzania zmian polega na optymalizacji całego procesu poprzez eliminację strat na poszczególnych etapach lub wręcz eliminację całych etapów. Na koniec opisuje się i wdraża konkretne działania wypełniające założenia optymalizacji. W fazie opisowej zidentyfikowano 27 etapów przez które pacjent musiał przejść do momentu rozpoczęcia leczenia, spośród których jedynie 16 uznano za wymagane. W efekcie zamiast $43 \%$ aż $94 \%$ pacjentów rozpoczęło leczenie już pierwszego dnia.

Pomimo generalnie pozytywnego nastawienia do metod szczupłego zarządzania, nie wszyscy odnoszą się do nich z entuzjazmem [4]. Krytycy wskazują przede wszystkim na brak statystycznie istotnego związku metody z satysfakcję pacjentów. Wskazują także na negatywny związek metody z kosztami i satysfakcją pracowników oraz na potencjalnie niespójne korzyści dla przepływu pacjentów i ich bezpieczeństwa. Pomimo silnego przekonania, że 'szczupłe metody' prowadzą do poprawy jakościowej w służbie zdrowia, w rzeczywistości brak jest jednoznacznych dowodów potwierdzających to stwierdzenie. 'Szczupłe metody’ stanowią najprawdopodobniej jedną z wielu strategii mogących mieć albo nie mieć wpływu na zapewnienie poprawy w ochronie zdrowia.

Jakkolwiek skuteczność konkretnych metod optymalizacji może być dyskusyjna, przyjmuje się, że odpowiednia organizacja pracy poprawia jakość leczenia. W dziedzinie radioterapii nie jest jużkwestionowane znaczenie maksymalizacji kultury bezpieczeństwa pracy; kwestionowane są natomiast środki zaradcze i konkretne metody. Wiadomo, że podniesienie kultury bezpieczeństwa pacjenta zależy od całościowego podejścia oraz że dużo zmian w opiece zdrowotnej nie prowadzi do trwałej poprawy. Wiadomo także, że konieczny jest wysiłek całego zespołu, aby leczenie pacjentów było precyzyjne i skuteczne. W tym procesie każdy członek zespołu RT musi wykonać określone zadania w celu zapewnienia jak najlepszej opieki nad pacjentem. W trakcie planowania leczenia i w procesie leczenia, komunikacja i transfer wiedzy wewnątrz zespołu mają zasadnicze znaczenie (ryc. 1).

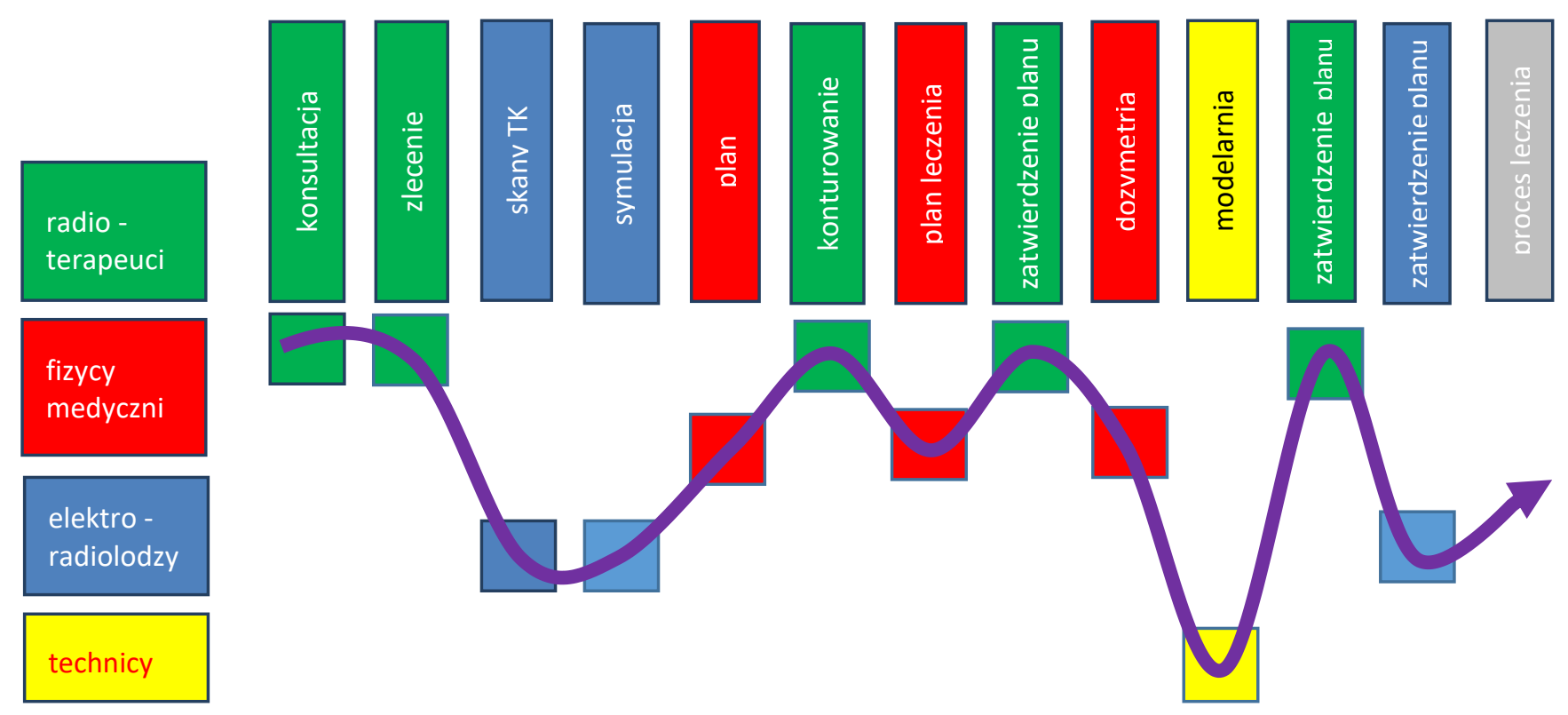

Ryc. 1 Radioterapia jako proces wielodyscyplinarny i wieloetapowy - czas przygotowania pacjenta do leczenia (1-10 dni). Krzywa obrazuje wykonywanie kolejnych etapów planowania przez poszczególne grupy zawodowe. 
W radioterapii, rozumianej jako proces multidyscyplinarny i wielostopniowy, każdy przestój w pracy może generować znaczne opóźnienia w rozpoczęciu leczenia. Przyczynami opóźnień w leczeniu są najczęściej: niedostateczna komunikacja, słaba koordynacja pracy oraz wadliwe zarządzanie. Szczególnie wiele problemów i błędów powstaje na etapie planowania leczenia. W zestawieniu WHO pt. „Analiza wypadków w radioterapii: zastosowanie analizy czynników ludzkich oraz systemu klasyfikacji” [5], wykazano, że 60\% wypadków ma swoje źródło w błędach ludzkich, spośród których 62\% wynika z nieuwagi. Do przyczyn takiego stanu rzeczy zaliczono: złą organizację pracy, błędy techniczne, zmiany w przebiegu leczenia, zmęczenie i stres personelu oraz kiepską komunikację i pracę zespołową.

Dla przeciwdziałania wypadkom zasugerowano wprowadzenie różnorakich działań naprawczych w strukturze i kulturze pracy oraz w procedurach projektowych i dokumentacyjnych. Niektóre elementy strategii prewencyjnych, tj. trening i edukacja, są nakierowane na człowieka i cechują się zmienną skutecznością. Pozostałe są nakierowane na system i mogą cechować się bardzo dużą skutecznością. Są to różnego rodzaju reguły, standardy i strategie np.: przypomnienia, listy kontrolne i podwójne sprawdzanie. Mogą to być także uproszczania i metody standaryzacyjne opierające się o automatykę i komputeryzację a w skrajnych przypadkach czynności, funkcje i działania zblokowane, czyli zaprogramowane tak, by dało się je wykonać tylko w jeden określony sposób. W odniesieniu do bezpieczeństwa w radioterapii proponuje się w szczególności wprowadzenie list kontrolnych (checklists) oraz podwójnego sprawdzania [6]. Lista kontrolna jest to lista działań, zadań lub zachowań zestawionych zwięźle, tak by umożliwić czytelnikowi wykrycie obecności lub braku konkretnych punktów. Zwykle każdy z punktów jest odznaczany po jego wykonaniu, zweryfikowaniu lub zidentyfikowaniu poprzez zaznaczenie na liście. Poprzez wypełnianie dedykowanych i zintegrowanych list kontrolnych w każdym podprocesie zapewniony jest bezpieczny i wydajny proces pracy z pacjentami.

Sprostanie wymogom stałej poprawy jakości i efektywności pracy zespołów radioterapeutycznych w oparciu o strategie 'szczupłego zarządzania' może wymagać wprowadzenia specjalistycznego systemu oprogramowania. Celem ogólnym takich systemów jest usprawnienie przepływu informacji i poprawa bezpieczeństwa pacjenta poprzez uporządkowanie pracy oraz ułatwienie wewnętrznej międzydyscyplinarnej komunikacji między członkami zespołu RT [7]. Wspomagają one działanie instytucji przez zarządzanie kadrami tak by konkretne zadania były wykonywane we właściwym czasie i przez właściwą osobę. Poza tym w radioterapii mogą nadzorować przebieg leczenia pacjenta, dostarczając informacji na każdym etapie leczenia. Systemy te zapewniają użytkownikowi szybką wizualizację pacjentów w procesach przygotowania do leczenia oraz samego leczenia. W ostatnich latach wiele jednostek wyposażyło z powodzeniem swoje oddziały w takie systemy. Ich wdrożenie pozwoliło na polepszenie pracy z pacjentami poprzez usprawnienie przepływu pracy, integracjęlist kontrolnych oraz zblokowanie funkcji inarzędzi przypisywania zadań. Obecnie oferowane i rozwijane na rynku systemy zarządzania muszą być wystarczająco elastyczne aby uwzględnić efekty działań ulepszających np. wprowadzenia nowych metod leczenia lub nowych technik. Cechami która wyróżnia dobre systemy są możliwość łączenia w większe bloki, zgodność z innymi systemami w dziale RT i łatwość obsługi. Systemy takie mogą być zakupione jako gotowe rozwiązania oferowane dla radioterapii przez wyspecjalizowane firmy lub jako rozwiązania mniej kosztowne, ale opracowywane i rozbudowywane na miejscu (np. dział iTP). Przyjmuje się, że dalszy postęp w tej dziedzinie będzie zależał od tego czy całe systemy zmierzać będą ku bezpieczeństwu.

W styczniu 2011 roku Klinika MAASTRO połączyła szczupłe zarządzanie z usprawnieniami strukturalnymi i kulturowymi w celu podniesienia kultury pracy i bezpieczeństwa pacjentów. Wprowadzono zarówno zmiany o charakterze ogólnym jak i szczegółowym. Do pierwszych zaliczono: szkolenia, wymiana informacji, przeprojektowanie procesów, restrukturyzacja zarządzania, tworzenie zespołów wielodyscyplinarnych oraz wprowadzenie szkoleń zewnętrznych. Zmiany szczegółowe dotyczyły np. wymiany aparatów terapeutycznych, przeprojektowanie kontroli jakości, zastosowanie oprogramowania i digitalizacja danych pacjentów, digitalizacja tablic informacyjnych, przeprojektowanie rejestracji pacjentów, zmiany podczas pierwszej konsultacji czy optymalizacja opieki paliatywnej. Jednocześnie za najważniejszy czynnik niezbędny dla ciągłej poprawy kultury pracy i bezpieczeństwa uznano wprowadzenie zespołów multidyscyplinarnych. Efekty zmian mierzono corocznie przez trzy lata, oceniając 9 elementów składających się 5 poziomów bezpieczeństwa pacjenta. Na poszczególnych etapach wyniki wskazywały na spadek liczby zgłoszonych incydentów, poprawę opinii o sprzęcie, udoskonalenie obsługi zarządzania bezpieczeństwem, poprawę ogólnej 
percepcję bezpieczeństwa pacjenta i poprawę pracy zespołowej w poszczególnych jednostkach. Wyniki z roku 2015 potwierdziły trwałość realizowanych ulepszeń. Stwierdzono, że szczupłe zarządzanie może przyczynić się do poprawy kultury bezpieczeństwa pacjenta. Trwała poprawa wymaga jednak wprowadzania usprawnień do samego procesu klinicznego.

Poza działaniami w skali instytucjonalnej, procesy optymalizacyjne mają czasami charakter strukturalny, odnoszący się do całego systemu opieki zdrowotnej. Przykładem tak szerokiego systemu jest austriacki planu strukturalny dla zdrowia. Plan ten jest efektem kompleksowej analizy związku trendów w demografii i epidemiologii, stworzonym w celu określenia niezbędnej liczby centrów onkologii w Austrii. Do niedawna rozwój struktury ośrodków onkologicznych w Austrii oparty był o wyniki zachorowań w danym regionie oraz o możliwości techniczne. Na podstawie przedstawionej analizy zachorowalności pacjentów powyżej 65 roku życia w porównaniu z częstotliwością występowania nowotworów w populacji generalnej oraz średniej zachorowalności w roku 2015, wyliczono szacunkowe zachorowania w latach 2020 oraz 2030. Prognoza wskazuje na wzrost zachorowalności o około 13\% do 2030 r. w grupie 65 plus. Pomimo niepokojących trendów nie przewiduje się jednak zwiększenia liczby ośrodków onkologicznych w Austrii w latach 2020 - 2030. Warto zaznaczyć, że obecnie zauważalny jest deficyt nowej aparatury (głównie akceleratorów) co skutkuje wydłużeniem oczekiwania pacjentów na rozpoczęcie leczenia. Obecnie w Austrii brakuje 18 akceleratorów, w tym 2 w samym Wiedniu. Aby w przyszłości poprawić ten stan oraz wywiązać się z prawa konstytucyjnego, gwarantującego pacjentom dostęp do leczenia, rząd Austrii powinien do 2030 roku zakupić 40 aparatów terapeutycznych. W przeciwnym razie oczekiwanie na uzupełnienie planowanego zakupu akceleratorów będzie miało negatywny wpływ na wyniki leczenia. Nie ma zatem potrzeby otwierania nowych centrów.

\section{Podsumowanie}

Podczas Konferencji ESTRO 35 w Turynie dużo uwagi poświecono metodom optymalizacji zarządzania w opiece zdrowotnej bazującym na filozofii szczupłego myślenia. Podkreślano korzyści jakie niesie stosowanie tych zasad dla poprawy jakości i bezpieczeństwa w leczeniu, wskazując jednocześnie na konieczność świadomego posługiwania się nimi. Przestrzegano przede wszystkim przed traktowaniem szczupłego myślenia jako precyzyjnego remedium. Jak każda filozofia zarzadzania, szczupłe myślenie nie jest zestawem ścisłych reguł, stąd czasami nie daje pożądanych rezultatów. Wskazywano jednocześnie na szeroką gamę analogicznych rozwiązań optymalizacyjnych oraz kompleksowych systemów zarządzania, pomagających wykorzystywać efektywniej pracę personelu opieki zdrowotnej.

\section{Konflikt interesu / Conflict of interest}

Nie występuje / None

\section{Piśmiennictwo / References}

[1] Mazzocato P, Savage C, Brommels M, Aronsson H, Thor J. Lean thinking in healthcare: a realist review of the literature. Qual Saf Health Care 2010;19(5):376-382.

[2] Hendrich A, Chow MP, Skierczyński BA, Lu ZA. A 36-hospital time and motion study: how do medicalsurgical nurses spend their time? Perm J 2008;12(3):25-34.

[3] Kim CS, Hayman JA, Billi JE, Lash K, Lawrence TS. The application of lean thinking to the care of patients with bone and brain metastasis with radiation therapy. J Oncol Pract. 2007;3(4):189-193.

[4] Moraros J, Lemstra M, Nwankw C. Lean interventions in healthcare - do they actually work? A systematic literature review. Int J Qual Health Care. 2016;28(2):150-165.

[5] Portaluri M, Fucilli F, Bambace S, Castagna R, De Luca MC, Pili G, Didonna V, Tramacere F, Francavilla MC, Leone A. Incidents analysis in radiation therapy: application of the human factors analysis and classification system. Annali dell'Istituto superiore di sanita 2008;45(2):128-133.

[6] Heles B, Terblanche M, Fowler R, Sibbald W. Medication error prevention “toolbox" - Institute For Safe Medication Practices. Med Safe Alert 1999;4:1.

[7] Mans RS, Russell NC, Van der Aalst WMP, Moleman AJ, Bakker PJM. Transactions on petri nets and other models of concurrency IV. Lecture Notes in Computer Science 2010;6550. 